\title{
Elžbiefa Tabakowska
}

\section{Ikoniczność: podobieństwo i tertium}

comparationis

ABSTRACT. Tabakowska Elżbieta, Ikonicznośc: podobieństwo $i$ "tertium comparationis" [Iconicity: similarity and tertium comparationis]. „Przestrzenie Teorii” 2, Poznań 2003, Adam Mickiewicz University Press, pp. 103-118, ISBN 83-232-1333-X, ISSN 1644-6763.

The paper analyses the phenomenon of iconicity in relation to its significance for literary theory. One of the key notions in modern philosophy of language and linguistics, iconicity is seen as a motivated interrelation beween form and meaning. In this, it is akin to mimesis - one of the basic concepts in theory of literature. Based on similarity, iconicity requires a conscious presence of an observer, who discovers and states the existence of similarity by reference to a tertium comparationis. It occurs as an effect of a mental process, as an interface bewteen semantics (the level of conventionalized meaning) and pragmatics (the level of contextual modifications of meaning). Thus it is intrinsically subjective: a representation of things as seen by a cognizant mind. Defined as a similarity between a conceptual structure and a linguistic form created by the mind, iconicity is manifested as sequentiality, proximity or quantity of elements; it is either imagic or diagrammatic. As a property of all texis and all discourse, it blurs the traditional distinction between "literary" and "non-literary" uses of language: the difference reduces to one of quantity, which "literatury" being characterised by a larger quantity of motivated interrelationships combined with a lower level of their conventionalization.

The author concludes by claiming that - like mimesis - iconicity may be profitably discussed in terms of Roland Langacker's notion of subjectification, with the tertium comparationis present in the mind rher than in the external reality.

Ikoniczność, czyli motywowana współzależność między formą i treścią, jest jednym $\mathrm{z}$ istotnych zagadnień leżących w obszarze zainteresowań współczesnej semantyki. W językoznawstwie teoria znaku językowego Charles'a Sandersa Peirce'a [Peirce 1955] powraca jako alternatywa wobec de Saussure'owskiego postulatu arbitralności znaku językowego, stanowiącego do niedawna niekwestionowany aksjomat strukturalistycznych teorii języka. W kontekście badań teoretycznoliterackich zasadnicze pytanie dotyczy relacji między ikonicznością a mimesis - kategorią wywodzącą się od Arystotelesa, uznawaną za wyznacznik artystyczności tekstu poetyckiego i mającą za sobą długą i bogatą karierę. Według powszechnego rozumienia, istotą mimesis jest odtwarzanie rzeczywistości w dziele sztuki - w poezji, w malarstwie, w muzyce [Markiewicz 1996], a ikoniczność rozumiana jako izomorfizm formy i treści przekazu jest jednym ze środków, czy też narzędzi, które służą realizacji tego celu. 
Z punktu widzenia współczesnej nauki o języku i o literaturze, klasyczna definicja ikoniczności wymaga istotnej modyfikacji. „Motywowana współzależność" to relacja oparta na podobieństwie i jako taka wymaga obecności obserwatora, który istnienie owego podobieństwa dostrzega i stwierdza, w odniesieniu do wybranego przez siebie tertium comparationis. Innymi słowy, podobieństwo pojawia się tylko tam i tylko wtedy, gdy istnieje świadomy podmiot, który je zauważa i powołuje do istnienia. Nie jest już jedynie statycznym i obiektywnym stanem rzeczy, lecz staje się procesem zachodzącym w umyśle twórcy i odbiorcy przekazu. Takie podejście oznacza rozszerzenie zakresu klasycznego pojęcia - przesunięcie z płaszczyzny ustalonych znaczeń znaków językowych (semantyki) na płaszczyznę modyfikacji znaczenia, następującej pod wpływem szeroko pojętego kontekstu (pragmatyki). $\mathrm{O}$ istnieniu lub nieistnieniu ikonicznego odczytania znaków przesądzają takie czynniki, jak konkretny cel wypowiedzi, wiedza o świecie nadawcy i odbiorcy, wrażliwość estetyczna, kontekst sytuacyjny. Takie dynamiczne rozumienie zjawiska ikoniczności pojawia się zarówno w nowszych rozważaniach z zakresu teorii literatury [por. np. Mitosek 2002: 27], jak i w kognitywistycznych modelach języka [por.np. Langacker 1999]. W efekcie takiej zmiany postawy badawczej czysto formalne wyznaczniki „obiektywnej” ikoniczności - onomatopeja, fonestezja, symbolizm dźwiękowy, metafora brzmieniowa - od dawna opisywane zarówno w kontekście poezji, jak i struktury języka - tracą na znaczeniu, zaś punkt ciężkości przesuwa się w kierunku rozważań nad umiejętnością dostrzegania - lub stwarzania - relacji podobieństwa jako podstawową zdolnością ludzkiego umysłu. „Kompetencja w zakresie rozpoznawania i budowania ikoniczności” staje się jednym $z$ przejawów najbardziej podstawowego procesu określającego istotę konfrontacji poznającego umysłu $\mathrm{z}$ otaczającą go rzeczywistością: procesu kategoryzacji obiektów i zachodzących między nimi relacji. Podobnie jak metonimia i metafora, ikoniczność staje się więc „wstępnym warunkiem porozumienia w ogólnym procesie komunikacji" [Nöth 2000: 25, tłum. E.T.].

Tak rozumiana ikoniczność stawia przed badaczem szereg niełatwych do rozstrzygnięcia problemów teoretycznych i metodologicznych. Wywodząca się od Arystotelesa naturalistyczna orientacja „naiwnego realizmu", iluzjonistyczna doktryna, w myśl której nie ma różnicy między przedmiotem fizycznym i jego postrzeganym przez umysł obrazem, zaś struktury języka stanowią odbicie fragmentów otaczającego świata (ut pictura poesis), musi ustąpić orientacji kreacjonistycznej: umysł tworzy rzeczywistość, a język opisuje taki świat, jakim go widzi człowiek. A zatem językowe obrazy świata są nie tyle przedstawieniami, co reprezentacjami rzeczywistości [por. Mitosek 2002:37]. Ikoniczność zostaje 
zdefiniowana jako tworzone przez umysł podobieństwo między strukturą pojęciową i formą językową. Relacja między rzeczywistością, poznaniem i językiem warunkuje proces tworzenia pojęć, którego kolejne fazy obejmują percepcję (ogląd rzeczywistości), konceptualizację (proces poznawczy) i symbolizacje (formę językowego wyrazu). Określonym pojęciom odpowiadają określone formy, a motywacją takich polączeń może się stać taki lub inny rodzaj podobieństwa. Wyrażenia ikoniczne w języku nie wywodzą się wprost $\mathrm{z}$ procesów percepcyjnych, lecz są odzwierciedleniem struktur pojęciowych.

Podczas gdy w teorii literackiej języka definicja ta zdaje się odpowiadać współczesnym tendencjom w myśleniu o ikoniczności (i, szerzej, o mimesis), w językoznawstwie jej przyjęcie oznacza radykalne odejście od scjentystycznego strukturalizmu (zwłaszcza w wersji przyjmowanej przez modele generatywno-transformacyjne). Taki antropocentryczny postulat pociąga za sobą - w kategoriach modelu Peirce'a - przywrócenie do łask ,interpretanta”, czyli mówiąc inaczej, pragmatycznego kontekstu, który warunkuje zrozumienie wyrażeń językowych. Rozpoznanie podobieństwa między określoną strukturą językową i leżącą u jej podstaw strukturą pojęciową $\mathrm{z}$ reguły wymaga od odbiorcy przekazu językowego odwołania się do określonej konwencji interpretacyjnej. A skoro takie konwencje są często uwarunkowane kulturowo, ikoniczności nie można uznawać za zjawisko „naturalne” i „uniwersalne” w sensie absolutnym: ikoniczność jest wprawdzie uniwersalna jako odbicie uniwersalnych procesów umysłowych, ale jej konkretne przejawy są uwarunkowane językowo: określone języki sankcjonują określone realizacje. W efekcie „w każdym znaku ikonicznym tkwią bardziej lub mniej przez nas uświadamiane konwencjonalne zasady jego generowania i odczytywania. Te zasady mogą być głęboko związane z kulturą, w której wyrośliśmy" [Mayenowa 1973: 48]. W procesie rozwoju języka formy ikoniczne stają się elementami systemu i stopniowo gubią motywacyjną przejrzystość. Granica między „semantyką" i „pragmatyką” traci dogodną dla badacza ostrość, a Peirce'owskie „ikony” i „symbole” sytuują się na przeciwległych krańcach pojęciowego kontinuum.

Dla językoznawcy takie podejście do zagadnienia oznacza także rezygnację $\mathrm{z}$ fundamentalnej dla klasycznego strukturalizmu de Saussure'owskiej tezy o odrębności synchronicznych i diachronicznych badań nad językiem: stopniowe zanikanie ikonicznej motywacji jednostek i struktur w procesie ich konwencjonalizacji (czyli gramatykalizacja) jest dziś uważane za jeden $\mathrm{z}$ podstawowych mechanizmów zmian językowych [por. np. Givón 1995]. Natomiast przed teoretykiem literatury to zmienione spojrzenie otwiera zmodyfikowaną perspektywę interpretacyjną: teksty „artystyczne” czy „literackie” ukazują swoją odrębność od tekstów 
„informacyjnych” czy „nieliterackich” przede wszystkim jako różnicę ilościowa. Każdy bez wyjątku tekst jest „swoistym zapisem sposobu widzenia” [Sienkiewicz 1992: 29], a tekst odbierany jako „literacki” charakteryzuje się jedynie większą liczbą motywowanych współzależności między formą i treścią przy jednoczesnym obniżeniu stopnia ich skonwencjonalizowania. Innymi słowy, wyznacznikiem artystyczności tekstu staje się po prostu swego rodzaju koncentracja środków wyrazu, bardziej świadome (niż w codziennej praktycznej komunikacji) użycie „ogólnie dostępnego" języka, jego jednostek i regul.

Skoro, jak powiedzieliśmy, istota zjawiska ikoniczności tkwi w swoistości zapisu oglądu, to podobieństwo dotyczy nie tyle samych rzeczy i obiektywnie zachodzących między nimi relacji, ile właśnie sposobu ich widzenia. Obecność obserwatora jest warunkiem sine qua non, a to z kolei nieuchronnie pociąga za sobą element subiektywizmu, przed którym tak mocno, i tak nieskutecznie, bronią się nauki humanistyczne, starając się sprostać ideałom dwudziestowiecznego scjentyzmu. Rolę antidotum na "nieskrępowany subiektywizm i relatywizm” postmodernistycznych tendencji, o które często oskarża się niektóre nurty dzisiejszej humanistyki, pełni założenie tzw. realizmu doświadczeniowego. W kategoriach językoznawstwa kognitywnego oznacza to opis języka oparty na podstawowych (i zbadanych przez odpowiednie dziedziny współczesnej nauki), zdolnościach poznawczych ludzkiego umysłu: strukturyzacji przyswajanej wiedzy o świecie w ramach struktur poznawczych o różnym stopniu złożoności, kategoryzacji obiektów i zachodzących między nimi relacji na różnych poziomach abstrakcji, łączenia struktur prostszych w bardziej złożone i - co szczególnie istotne dla naszych dalszych rozważań - rozpoznawania podobieństw między strukturami [por. np. Langacker 1995: 14].

Postulat takiego epistemologicznego obiektywizmu pociąga za sobą pytanie o relacje między postrzeganiem (zmyslowym, przede wszystkim wzrokowym) i konceptualizacją, które ostatecznie przesądzają o kształcie wyrażeń językowych. Uniwersalne zdolności ludzkiego umysłu każą ludziom postrzegać obiektywnie istniejącą rzeczywistość według określonych uniwersalnych zasad, ale każdy akt konceptualizacji, czyli nadawania znaczenia, jest nieuchronnie uwikłany w jedyny i niepowtarzalny splot okoliczności, nazywany pragmatycznym kontekstem. Wyrażenia językowe są wprawdzie szczególową realizacją ogólnych abstrakcyjnych schematów (czyli reguł gramatycznych), ale za każdym z nich kryje się jakiś „swoisty sposób widzenia”. Przejście „od szczegółu do ogółu" - czyli mówiąc inaczej, proces kształtowania się konwencji językowych - okazuje się nieostre, co oczywiście pociąga za sobą również zatarcie granic między „semantyką" i „pragmatyką". 
Można by w tym miejscu zasadnie zapytać, jaki jest związek wszystkich tych rozważań z ikonicznością. Otóż po pierwsze, wyjściowego elementu izomorficznych „motywowanych współzależności” należy szukać nie w konkretnych lub abstrakcyjnych obiektach, lecz w sposobie ich postrzegania (konceptualizacji). Po drugie, kluczowe dla zjawiska ikoniczności „widzenie”, pojmowane zarówno dosłownie, jako percepcja wzrokowa, jak i jako metaforyczne rozszerzenie, oparte na metaforze WIDZIEĆ TO WIEDZIEĆ i zaświadczone $\mathrm{w}$ takich potocznych wyrażeniach, jak Nie widzę w tym więhszego sensu, Widzę, że się ze mnq̨ zgadzasz, Od razu zobaczyli, o co mu chodzi, itd., określa przyjęty przez obserwatora punkt widzenia i roztaczajacą się $\mathrm{z}$ niego perspektywę. Cytując Langackera, „nie ulega wątpliwości, że przestrzeń i postrzeganie wzrokowe są w procesach poznawczych absolutnie fundamentalne" [1995: 65]. Ikoniczność jest zatem cechą nie tylko przedstawień oglądowych (wizualnych, postrzeżeniowych), ale i wyobrażeniowych [por. Markiewicz 1996: 8]. Po trzecie wreszcie, ikoniczność podlega konwencjonalizacji w momencie, gdy utrwalony w języku punkt widzenia indywidualnego obserwatora uzyskuje status usankcjonowanej struktury językowej, a sam obserwator staje się Langackerowskim „obserwatorem uogólnionym”.

Taki właśnie obserwator pojawia się w tle tych opisów ikoniczności, które poszukują jej przejawów na płaszczyźnie systemu języka (langue). Badacze dostrzegają zjawisko ikoniczności na wszystkich poziomach językowych i od dawna opisują je w ramach różnych teorii języka. Fonetycy mówią o fonestezji i symbolice dźwięków mowy, leksykolodzy - o słowach-symbolach, badacze morfologii i składni - o izomorficznej strukturze gramatyki. Opisy ikoniczności $w$ odniesieniu do większych struktur - przede wszystkim tekstów poetyckich - pozostają tradycyjnie domeną filozofów języka i teoretyków literatury ${ }^{1}$ Natomiast rozważania, które w ramach ustalonych podziałów należałoby zaklasyfikować jako ,językoznawcze" zaowocowaly ustaleniem trzech (niekontrowersyjnych) zasad ikoniczności; badania nad językami odmiennymi pod względem typologicznym wskazują, że można tym zasadom przyznać status uniwersalnych prawidłowości.

Zasada pierwsza to zasada sekwencyjności, znana od dawna pod nazwą ordo naturalis: linearny porządek struktury językowej jest izomorficzny w stosunku do chronologii opisywanych zdarzeń. Fiński językoznawca Nils Enkvist określa ten typ ikoniczności mianem „doświadczeniowej” i wyróżnia w jej obrębie trzy podtypy: ikoniczność zorientowaną

1 Wybór nowszych prac i obszerną bibliografię znaleźć można w ukazującym się od 1999 roku cyklu: Iconicity in Language and Literature: Ninny \& Fischer 1999, Fischer and Nänny 2000, Müller \& Fischer 2002. 
na działanie (typowy przykład: instrukcja obsługi), ikoniczność zorientowaną na lokalizację (typowy przykład: przewodnik turystyczny) oraz ikoniczność zorientowaną na czas (typowy przykład: kronika) [Enkvist 1990]. Opisując poszczególne podtypy, Enkvist szuka w pierwszym rzędzie konwencjonalnych wyznaczników syntaktycznych (np. przesunięcie frazy okolicznikowej na początek zdania); samo zjawisko jest jednak doskonale znane badaczom literatury jako podstawa narracyjnej mimesis.

Kolejną zasadą jest zasada proksymalności, wywodzona od tzw. pierwszego prawa Behaghela (das geistig Zusammengehörige auch eng zusammengestelt wird) [Behaghel 1932]. W myśl tej zasady, elementy uważane za bliskie sobie na płaszczyźnie pojęciowej (a więc konceptualizacji) pojawiają się obok siebie również w strukturze językowej. Zasadą tą tłumaczą językoznawcy takie zjawiska, jak tworzenie zrostów w morfologii czy warianty szyku w obrębie frazy nominalnej.

Zasada trzecia wreszcie to zasada ilości, rozumiana jako tendencja do zachowywania ilościowej proporcji między formą i treścią: im więcej treści, tym więcej formy. Leży ona u podstaw takich zjawisk, jak niedystynktywne wzdłużenie samogłoski (np. to dluuuga historia), reduplikacja (np. tworzenie liczby mnogiej poprzez podwojenie elementu w liczbie pojedynczej: $w i l$-wil $=$ ang. wheel + wheel $=$ rower $\mathrm{w}$ Pidgin English) czy powtórzenie retoryczne (np. szedl, szedl $i$ szedl).

Rozważania nad poszczególnymi zasadami ikoniczności systemowej doprowadziły do wyróżnienia - dla celów badawczych - dwóch podstawowych typów ikoniczności: ikoniczności obrazowej i ikoniczności diagramatycznej. Opierając się na semiotyce Peirce'a, ikoniczność pierwszego typu definiuje się jako prymarną, przejawiającą się jako relacja typu ,jeden do jednego" między znakiem i jego desygnatem, czyli - w terminologii de Saussure'a - między signifiant i signifié. Ikoniczność obrazowa ma w ramach tej taksonomii charakter bezpośrednio postrzeżeniowy; często przekracza ona granice języka i staje się zjawiskiem czysto wizualnym (jak na przykład w często omawianym przypadku ikonicznej wartości carmen figuratum). Natomiast ikoniczność diagramatyczna określana jest jako sekundarna; ma ona charakter relacyjny i abstrakcyjny, a zasadza się na izomorficznej odpowiedniości między określonym wzorcem strukturalnym i wiązanym z nim znaczeniem. Mówi się w tym kontekście albo o relacji między układem znaków językowych i odpowiadającym mu układem desygnatów (tzw. ikoniczność reprezentująca, ang. Representational), albo też o wewnętrznych relacjach w obrębie systemu (tzw. ikoniczność wewnątrzsystemowa, ang. Intrasystemic) [por. Johansen 1996]. Podział ten znany jest zresztą - choć pod innymi nazwami badaczom literatury [por. np. dyskusję o wieloznaczości kategorii mimesis w: Mitosek 2002]. 
Szczegółowe rozważania na temat mimesis jako naśladowania mowy, choć interesujące z punktu widzenia lingwistyki tekstu i dyskursu, pozostawimy do innej okazji, w tym miejscu koncentrując się na naśladowaniu rozumianym jako przedstawienie sposobu widzenia rzeczywistości. Zacznijmy od rzeczy najprostszej: od nazw obiektów fizycznych, które najczęściej pojawiają się w dociekaniach językoznawczych związanych z ikonicznością. Na przykład, charakteryzując podstawowe dla badań etnolingwistycznych pojęcie językowego obrazu świata, Jerzy Bartmiński [1990: 112-113] podaje jako przykład zestaw różnych nazw „źrenicy oka” w polszczyźnie. Trzy różne nazwy tego obiektu - ogólnopolski rzeczownik źrenica, staropolska zienica i gwarowe lalka, panien$k a$ i człowieczek - odpowiadają zdaniem autora trzem różnym punktom widzenia: funkcjonalnemu (por. spojrzeć, spozierać), percepcyjnemu (por. ziać, ziewać w znaczeniu „otwierać") oraz interakcyjnemu (odbicie obrazu rozmówcy). Każda powstała w wyniku wyboru jednej $\mathrm{z}$ cech widzianego przedmiotu oglądu, czyli tego, co $\mathrm{w}$ teorii widzenia nazywane jest „szczególnym aspektem rzutowym”, tym samym usuwając na dalszy plan pozostałe aspekty. Analogię z postrzeganiem wizualnym przywołuje także gramatyka kognitywna Langackera, która - odwołując się do układu figury i tła w psychologii postaci - mówi w tym kontekście o pragmatycznej „wyrazistości cechy” (salience). U podstaw tworzenia nazwy leży zatem metonimiczny wybór pars pro toto, będący ikonicznym odbiciem swoistego sposobu jego oglądu. W procesie poznania powstaje jednak ostatecznie "pojęcie trójwymiarowe”, które nie jest związane z żadnym określonym aspektem: pojawia się wiedza o przedmiocie, stanowiąca „sumę obserwacji pod niezliczoną ilością kątów” [Arnheim 1978: 116]. Ikoniczna nazwa konwencjonalizuje się i traci swą pierwotną ikoniczną przejrzystość. Innymi słowy, reprezentacja obiektu - „struktura intencjonalna, efekt nakierowanej na przedmiot świadomości" [Mitosek 2002: 37] - staje się jego konwencjonalnym przedstawieniem.

Analogicznie wykazać można ikoniczne podłoże kategorii gramatycznych, które w kognitywistycznej teorii języka również służą symbolizacji treści pojęciowych. Weźmy dla przykładu kategorię aspektu czasownika w języku polskim. Używając aspektu dokonanego, np. w zdaniu Napiszę list w sobotę, obserwator konceptualizuje czynność „pisania” na wzór przedmiotu fizycznego o wyraźnych konturach. Kognitywista powie, że podstawą takiej konceptualizacji jest pojęciowa metafora ontologiczna BYTY ABSTRAKCYJNE TO PRZEDMIOTY FIZYCZNE. Nadawszy „pisaniu” kształt przedmiotu, obserwator umieszcza go następnie w określonym przedziale czasu, który pojmowany jest jako pojęciowo analogiczny do fizycznego pojemnika (por. gość $w$ dom). Cecha „wykonturowania”, zaobserwowana jako atrybut przedmiotów fizycznych, została 
uznana za wyrazistą i przeniesiona, na zasadzie podobieństwa, na przedmiot abstrakcyjny („pisanie”). W procesie rozwoju języka kategoria aspektu polskiego czasownika skonwencjonalizowała się, tracąc swą pierwotną ikoniczną przejrzystość. Ale u jej podstaw tkwi oparte na podobieństwie metonimiczne przeniesienie, które w tym przypadku lączy domenę przestrzeni $z$ domeną czasu, a więc ma charakter rozszerzenia metaforycznego.

Przejście od metonimii (zjawiska zachodzącego w obrębie jednej domeny pojęciowej) do metafory (która jest przeniesieniem atrybutów $\mathrm{z}$ jednej domeny pojęciowej do innej) jest plynne. Poświęcono mu w ostatnich latach wiele uwagi, i nie tu miejsce na szczegółowe rozważania. W dalszym ciągu chcielibyśmy pokazać nie tyle ikoniczność „martwą", która zajmuje językoznawców, ile proces twórczego użycia języka, który wykorzystuje ogólne zasady po to, aby ją wyeksponować i „ożywiç”.

Przykład pierwszy dotyczy podstawowej operacji tekstotwórczej: niemetaforycznego opisu sceny:

Jechaliśmy w ciemnościach, wzdłuż ogrodów i domów willowych. Przed domem $\mathrm{z}$ numerem 98 wysiadłam $\mathrm{z}$ auta $\mathrm{i}$ zadzwoniłam do drzwi.

Otworzyła mi starsza pani.

Stała w głębi, w jasnym świetle, jak w punktowym reflektorze, który ją wydobywał z czarnej scenerii. Miała bujne, siwe, wysoko upięte włosy, duże brazowe oczy, niepewny uśmiech i uważne spojrzenie.

- Tak właśnie powinna pani wyglądać - ucieszyłam się - ale muszę teraz iść spać.

Podała mi herbatę w beżowym salonie, pokazała mi różową łazienkę, wielkości mojego największego warszawskiego pokoju i zaprowadziła do bialej sypialni.

[Hanna Krall, Powieść dla Hollywoodu, s. 7, podkr. E.T.]

Łatwo zauważyć, że tym, co narratorce „rzuca się w oczy” (według potocznej metafory, oddającej sens pojęcia relacji między figurą i tłem) w opisywanej scenie, jest gra światła i cienia oraz kolor. Ksztalty przedmiotów pozostają w znacznej mierze $\mathrm{w}$ sferze Ingardenowskich miejsc niedookreślenia. Jest to sposób widzenia odbiegający od postrzeżeniowych prawidłowości, ponieważ to właśnie kształt lepiej ujawnia różnice jakościowe i wobec tego jest $\mathrm{w}$ konfrontacji ze światem lepszym środkiem postrzeżeniowym niż barwa [por. Arnheim 1978: 334-335]. Tymczasem wyróżnione $\mathrm{w}$ przytoczonym fragmencie przymiotniki będące nośnikami koloru są nicmal jedynymi przywołanymi w obrazie cechami przedmiotów. Żaden $\mathrm{z}$ wymienionych $\mathrm{w}$ opisie elementów - jasne światho, czarna sceneria, siwe wlosy, brazowe oczy, beżowy salon, różowa łazienka, biata sypialnia - sam w sobie nie zostałby zapewne łatwo uznany za wyrażenie ikoniczne. Natomiast ich nagromadzenie buduje iko- 
niczny obraz całej sceny, oglądanej z określonego punktu widzenia (narratorki). Stwarza wrażenie pewnego oddalenia, dystansu, który zaciera ksztalty i zamazuje szczególy. Portret bohaterki staje się impresjonistycznym szkicem, obraz jej domu - sekwencją barwnych plam. Zaciera się także narracyjność opisu: wejście narratorki do domu, przejście do salonu, a potem do łazienki i sypialni wynika wyłącznie z logiki lektury; nieciągłość czasu i przestrzeni w rzeczywistości przedstawionej, o których pisał Ingarden, buduje się nie tylko ze skokowej sekwencyjności, ale także $\mathrm{z}$ braku czasowników w pierwszej osobie: narratorka odnotowuje na początku sceny zaledwie trzy czynności, których jest podmiotem: wysiadtam z auta, zadzwonilam do drzwi, ucieszylam się. Dalsze partie narracji to czynności Izoldy R.; narratorka widzi siebie w roli biernego przedmiotu podlegającego cudzym działaniom (co gramatycznie wyraża się celownikiem zaimka osobowego $\mathrm{mi}$ ). Cały opis ma zapewne przekazać stan emocjonalny narratorki, zmęczenie pełnym wrażeń dniem, potrzebę odpoczynku i snu, która wyraża się odbiegającym od towarzyskich konwenansów obcesowym stwierdzeniem ale ja musze teraz iść spać. Interpretacja owej „motywowanej współzależności” jest oczywiście zadaniem dla badacza literatury, ale opis jej struktury należy do badacza języka.

Jak powiedzieliśmy, proces bezpośredniego postrzegania wzrokowego wymaga przyjęcia określonego punktu widzenia i w konsekwencji wyboru określonych „aspektów rzutowych” kosztem innych. Natomiast „ogląd wewnętrzny” umożliwia jednoczesną obserwację obiektu z różnych punktów widzenia. Odwzorowanie takiego oglądu na płaszczyźnie wyrażeń językowych napotyka nieprzezwyciężalną trudność w postaci linearności języka. Dowodów upartej walki z tym ograniczeniem dostarczają liczne wysiłki poetów (jako przykład można by przywołać poezję Mirona Białoszewskiego). W malarstwie stanowi ona istotę kubizmu, który był dążeniem artysty do połączenia na obrazie wielu aspektów rzutowych w celu ukazania pełniejszego obrazu przedmiotu. „Dla ocenienia rezultatu odbiorca miał przefruwać na skrzydłach umysłu od jednego ujęcia perspektywistycznego do drugiego, bądź też przebywać równocześnie w różnych miejscach" [Arnheim 1978; 141]. Przyjrzyjmy się takiemu „kubistycznemu” opisowi przedmiotu:

Miał ręce dokladnie takie jak we włoskim albumie, narysowane przez Leonarda da Vinci. Skąd Leonardo wiedzial, że akurat on będzie miał takie ręce? I że ona, która od dziecka, co jakiś czas, kiedy ojca nie było w domu, włazila na krzesło i ściągała album z najwyższej półki, by popatrzeć na te ręce - że ona spotka je i ich dotknie? Szczupłe, wyraźne dłonie z długimi palcami, do których idealnie pasowałaby wąska, złota obrączka, najwęższa $z$ tych, jakie widziała w życiu, na 
palcu zmarłej ciotki ubieranej do trumny, tylko taka obrączka, nic więcej. Pasowałaby i dlatego, że prawie nie byłoby jej widać - miał skórę koloru złota. Nie opaloną, nie smagłą, a właśnie koloru złota przez cały rok, w zimie także... Te ręce wyglądały jak dekoracja, gdy kładł je na oparciu fotela...

[Hanna Krall, Powieść dla Hollywoodu, s. 10-11]

Opis rąk męża Izoldy R. to obraz, który - przełożony na obraz plastyczny - mógłby powstać z nałożenia na siebie kilku klisz, na których utrwalono kolejne ujęcia tych samych (lub takich samych) przedmiotów. Sekwencyjność wymuszona prawami języka nie jest w przytoczonym fragmencie sekwencyjnością chronologiczną; jest to odbicie umysłowej „manipulacji” przedmiotami, dzięki której ukazują one oku obserwatora rozmaite aspekty: na obraz rąk mężczyzny nakłada się wizerunek namalowany przez Leonarda da Vinci; na obraz dłoni - obraz palca w złotej obrączce, przeniesiony $z$ innego miejsca i innego czasu; na kształt nakłada się kolor, na obraz pozbawiony kompozycji - układ wymuszony tłem w postaci oparcia fotela. Co więcej, każdy z tych obrazów zostaje pomnożony za sprawą iteratywności niedokonanego trybu czasowników (wtazita, ściagata, ktadt), dodatkowo wzmocnionej określeniami wyrażającymi powtarzalność czynności (co jakiś czas) i ciągłość stanów (przez caly rok). Jak poprzednio, żaden $\mathrm{z}$ elementów opisu nie mógłby zostać uznany za „ikoniczne odwzorowanie”. Natomiast ich nagromadzenie w całym fragmencie staje się odbiciem swoistego sposobu oglądu obiektu, $\mathrm{z}$ różnych punktów widzenia - w przestrzeni i w czasie. „Kubistyczna struktura” tekstu oddająca „kubistyczność” przedstawienia wyobrażeniowego - „manipulowanie” mentalnym obrazem rąk mężczyzny, wieloaspektowość i zwielokrotnienie „wewnętrznego oglądu” - służy odwzorowaniu niemal obsesyjnej miłości Izoldy R. do męża. Jak poprzednio, interpretacja należy do badacza literatury, rzeczą językoznawcy jest ukazanie leżących u podstaw tekstu mechanizmów.

O ile ikoniczność pierwszego opisu opierała się wyłącznie na metonimii, o tyle opis drugi stoi już niejako na pograniczu metafory: rozmaite aspekty obiektu (wybrane na zasadzie metonimii) tworzą sieć współzależności (a więc określoną strukturę pojęciową). Z kolei, jeśli przyjąć, że metafora pojęciowa rodzi się z wykorzystania jednej struktury pojęciowej (domeny) do opisu innej, należy oczywiście także przyjąć, że strukturze pojęciowej odpowiadającej elementom świata przedstawionego i zachodzącym między nimi relacjom można narzucić odniesienie do innej struktury pojęciowej. Jorgen Johanson opisuje ten mechanizm jako „ikonizowanie przez alegoryzacje” (iconizing through allegorization); [Johansen 2002: 385-403] i - jak na badacza literatury przystało - omawia go w odniesieniu do tekstów literackich, tradycyjnie uznawanych za alegoryczne (Nowy Testament, Proces Kafki). Jednakże zgodnie z naturą 
metafory pojęciowej, metaforyczne przeniesienie wykorzystuje jako domenę źródłową, pojęciowo prostszą od domen pojęciowych abstrakcyjnych, czyli bardziej złożonych. Podstawową metaforą pojęciową jest przytoczona już wyżej metafora ontologiczna BYTY ABSTRAKCYJNE TO PRZEDMIOTY - filar, nauk ścisłych, filozofii i poezji.

Pamiętając o tym, co zostało powiedziane na wstępie niniejszych rozważań o relacji między „literaturą" i „nie-literaturą”, alegoryzacji, czyli „doszukiwania się innych znaczen”" [Johansen 2002: 399], nie sposób uznać za wyłączną domenę tekstów artystycznych. Potwierdzeniem niech będzie ostatni przykład zaczerpnięty z "Gazety Wyborczej”. Poniżej przytaczam go in extenso:

Polityczny zamęt ostatnich kilku miesięcy prowokuje do pisania czarnych scenariuszy dla Polski. Tylu wątpliwości dotyczących stabilności demokratycznego ładu, takiego zniechęcenia do polityki i wolnego rynku nie bylo od 1989 roku. Zbliżająca się integracja z Unią Europejską, wieńcząca wieloletnie wysiłki elit i będąca ukoronowaniem aspiracji większości Polaków, zamiast przebiegać $\mathrm{w}$ atmosferze zbiorowego entuzjazmu, przypomina finisz wyczerpanego maratończyka, który tuż za metą pada bez tchu.

Polski nie stać na dalsze pogrążanie się w apatii i wycofaniu. Trzeba nowego impulsu, który wyzwoli naszą aktywność, byśmy nie stali się unijnym, wiecznie narzekającym maruderem.

Zrozumiałe są ograniczenia mniejszościowego rządu i pozbawionego większości parlamentu. Warto więc ożywić dialog społeczny toczony poza parlamentem, spróbować zawrzeć spektakularne porozumienie. Nazwijmy je paktem, spoleczną umową - to bez większego znaczenia. Nie szyld decyduje o powodzeniu dialogu, ale dobra wola partnerów $\mathrm{i}$ ich troska o dobro wspólne.

Spętanej historycznymi urazami „Solidarności” warto zaś przypomnieć, że kolejne etapy polskich przemian wyznaczane były przez umowy społeczne z 1980 i 1989 r. Ich najważniejszym sygnatariuszem zawsze była „S”.

Skoro wtedy była $w$ stanie usiąść do stołu $z$ ludźmi dyktatury, nie powinna dziś uchylać się od dialogu $\mathrm{z}$ demokratycznie wyłonionym rządem. Jakkolwiek liderzy „S" by to tłumaczyli, i tak będzie to równoznaczne $z$ uchylaniem się od odpowiedzialności za kraj.

[Rafał Kalukin, GW, 12 marca 2003]

Treść tego krótkiego felietonu jest oparta na schemacie wyobrażeniowym „przemieszczania”; jest to połączenie schematu „zdarzenia” $z$ miejscem, w którym zaczyna się czynność lub stan (czyli tzw. „źródłem”), drogą, wzdłuż której przemieszcza się obiekt (czyli tzw. „ścieżką") oraz miejscem, do którego ów przemieszczający się obiekt zmierza (czyli tzw. „celem”). Schemat „źródło - ścieżka - cel” jest podstawowym sposobem naszego rozumienia pojęcia ruchu obiektu w przestrzeni, przy czym może to być ruch fizyczny w trójwymiarowej przestrzeni (np. Janek jedzie do domu), abstrakcyjny ruch przebiegający w czasie (np. Jechat az do 
siódmej wieczorem) lub ruch metaforyczny (np. Wszyscy doszliśmy do tego wniosku $)^{2}$. W cytowanym tekście mamy do czynienia z ostatnim z tych przypadków. Obiektami ruchomymi są „proces integracji”, „Polska” i „Solidarność”, a „ścieżka” prowadzi ku Unii Europejskiej. Na podstawowy schemat „źródło - ścieżka - cel” nakładają się wartości aksjologiczne zgodne $\mathrm{z}$ tzw. metaforami orientacyjnymi DOBRE TO GÓRA i DOBRE TO NAPRZÓD, oraz ich odwrotnościami, ZŁE TO DÓŁ i ZŁE TO DO TYŁU [por. Lakoff i Johnson 1988]. A więc integracja zbliża się i powinna przebiegać tak, aby stać się wieńczqcym wysitki ukoronowaniem. Niedobrze, gdyby Polska miała się pogrążać zamiast wykazać aktywność i gdyby miała zostać wlokącym się z tyłu maruderem, a integracja nie mogła kontynuować ruchu, ponieważ tuż za meta pada bez tchu. Spętana "Solidarność" nie może już skutecznie posuwać się w stronę celu, choć ma za sobą skutecznie przebyte kolejne etapy. Celem „Solidarności" jest dialog, i wobec tego nie powinna schodzić z wytyczonej drogi (uchylać się). Jak widać, poszczególne elementy calego obrazu tworzą spójny system odniesień do nacechowanego aksjologicznie schematu.

Jak $\mathrm{w}$ poprzednich przypadkach, żaden $\mathrm{z}$ elementów składowych sam $w$ sobie nie spełnia definicji ikoniczności, natomiast wszystkie razem składają się na układ relacji odpowiadający relacjom zachodzącym między elementami schematu. W skali całego tekstu ogólna metafora pojęciowa buduje się na jego ikonicznym odwzorowaniu.

$\mathrm{Na}$ podobnej zasadzie działa wspomniana wyżej diagramatyczna ikoniczność wewnątrztekstowa. Na przykład doniesienie o wypadku, który przytrafił się pewnemu polskiemu sportowcowi podczas wizyty $\mathrm{w}$ nocnym klubie, dzienikarz opatrzył tytułem Veni, saltavi, procidi [,Gazeta Wyborcza", 12 października 2001]. Jest to oczywisty przykład ikoniczności sekwencyjnej $\mathrm{w}$ połączeniu $\mathrm{z}$ ilościową: seria trzech krótkich czasowników określających kolejne etapy zdarzenia odwzorowuje lakoniczność wyjaśnień bohatera artykułu, któremu wyraźnie nie zależy na ujawnianiu szczegółów wypadku, a sam fakt uważa za niewart dziennikarskiego komentarza. Natomiast użycie łacińskich odpowiedników jego wypowiedzi (przyszedtem, zatańczyłem, przewrócitem się) przywołuje inny diagram: klasyczne veni,vidi,vici Juliusza Cezara, a wraz z nim całą gamę „alegoryzujących" znaczeń.

Czas na podsumowanie.

Mówiąc o istotnym dla kognitywistycznych analiz języka zjawisku subiektyfikacji, czyli stopnia, w jakim konceptualizator zaznacza swoją obecność w wypowiedzi, Langacker [1999] stwierdza, że ten „subiektywny" element jest zawsze obecny, ujawniając się z większą lub mniejszą wyrazistością. W konceptualizacjach maksymalnie obiektywnych rola

${ }^{2}$ Szerzej o tym schemacie (i o innych schematach zdarzeń) w: Tabakowska 2001. 
obserwatora polega jedynie na odnotowaniu silnie (obiektywnie) motywowanych relacji między obiektami. Natomiast konceptualizacja maksymalnie subiektywna polega na powołaniu takiej relacji do istnienia: podmiot staje się więc jej twórcą. Typ pośredni, zwany przez Langackera "złagodzeniem" (attenuation), polega na ustaleniu relacji, która jest motywowana słabiej niż to ma miejsce w przypadku konstrukcji obiektywnych. Jeśli przyjąć, że jedną z takich relacji jest podstawowa dla procesów poznawczych relacja podobieństwa, subiektyfikacja znajduje bezpośrednie zastosowanie $\mathrm{w}$ rozważaniach nad ikonicznością i punktem widzenia. I rzeczywiście: Langackerowską skalę ( $\mathrm{z}$ jej dwoma punktami skrajnymi i umownym „środkiem”) odnajdujemy na przykład w rozważaniach Bartmińskiego o językowym obrazie świata [Bartmiński 1990: 109], który wprowadza rozróżnienie między „wizją świata” (view of the world, obrazem widzianym, choć nie istniejącym w obiektywnej rzeczywistości) i (językowym) „obrazem świata” (das sprachliche Weltbild), który „tak silnej implikacji podmiotu nie zawiera, punkt ciężkości jest w nim przesunięty na przedmiot”. Langackerowskie „złagodzenie” znajduje w polszczyźnie odpowiednik w postaci słowa „wizerunek" (image), który jest definiowany jako „podobizna” (portret, fotografia). Językowa „wizja” stopniowo zmienia się $w$ procesie rozwoju języka w konwencjonalny „obraz". Zawarta w nim pierwotnie ikoniczność swoistego punktu widzenia zamienia się w zobiektywizowaną oczywistość. Innymi słowy, wyrażająca „wizję" struktura staje się konwencjonalną jednostką języka.

Natomiast w ikoniczności „artystycznej” ta kolejność niejako ulega odwróceniu: z konwencjonalnych obrazów powstaje mniej lub bardziej zabarwiony subiektywizmem wizerunek lub całkowicie subiektywna wizja. Bierne rozpoznanie zostaje zastąpione aktywnym procesem tworzenia rzeczywistości. Ikoniczność „ożywa”.

Kierunek „od subiektywizmu do obiektywizmu” (czy też „od wizji do obrazu") wyznacza proces powstawania stylu, szkoly - tak w sztukach plastycznych (por. np. impresjonizm, kubizm czy abstrakcjonizm jako usankcjonowany konwencją, ustalony sposób widzenia), jak i w sztuce słowa. Relacja bezpośredniego metonimicznego podobieństwa nabiera znamion metafory. W niedawnej recenzji filmu Petera Naessa Elling krytyk pisze:

W obrazie Oslo początkowo dominują bliskie, ciasne plany, punkt widzenia człowieka cierpiącego na lęk przestrzeni, który patrzy pod nogi, boi się podnieść głowę. Z biegiem filmu pole widzenia poszerza się, świat staje się coraz bardziej dostępny, dyskretnie opiekuńczy.

[T. Sobolewski, „Gazeta Wyborcza”, 13 marca 2003]

Jest to wyraźny przykład „ikonizacji”, o której pisze Johansen: krytyk - zapewne $\mathrm{w}$ zgodzie $\mathrm{z}$ zamierzeniem reżysera filmu - interpretuje 
dosłowny punkt widzenia kamery jako ikoniczną reprezentację subiektywnej „wizji świata” bohatera filmu.

I jeszcze jeden przykład. Projektant powstającego przy krakowskim uniwersytecie Auditorium Maximum tak opisuje swój projekt:

Schody skojarzyliśmy ze stopniami, jakie nauka stawia przed każdym, kto chce coś zdobyć. [...] Kształtowaliśmy je tak, by pokazać, że droga do wiedzy jest drogą podzieloną na poszczególne etapy, drogą zdobywania kolejnych stopni, a także momentów na refleksję i pewnych wyborów.

[St. Dańko, Alma Mater 33, wrzesień 2001]

Tym razem „ikonizacja” jest oparta na przekładzie (konwencjonalnej) metafory ZDOBYWANIE WIEDZY TO DROGA W GÓRĘ na ,język" architektury. W obu przykładach język naturalny jest kolejnym językiem przekładu: pełni rolę pośrednika między sposobem widzenia wycinka rzeczywistości i strukturą pojęciową, która ten sposób widzenia kształtuje. W językowym opisie brak formalnych systematycznych wyznaczników ikoniczności, natomiast oba teksty są złożonymi diagramatycznymi ikonami.

W stwierdzeniu, że odnajdywanie podobieństw między strukturami pojęciowymi wszystkich poziomów jest podstawową zdolnością ludzkiego umysłu, nie ma oczywiście nic odkrywczego. Podobnie jak w twierdzeniu, że wyrażanie owych podobieństw - mimesis - jest wspólną zasadą wszelkich sztuk [por. Markiewicz 1996: 12, Sienkiewicz 1992: 29]. Pozostaje pytanie o wzajemną relację kategorii mimesis i kategorii ikoniczności. Jeśli rozumieć ikoniczność wyłącznie jako relację obiektywnie motywowanego podobieństwa między przedmiotem i znakiem - w szczególności znakiem językowym - i ograniczyć rozważania do zjawisk systemowych, a więc do podobieństwa motywowanego obiektywnie (w rozumieniu Langackera) i utrwalonego w językowej konwencji, mimesis jawi się jako Langackerowska subiektyfikacja: reprezentacja przedmiotów i zachowań (a także cudzych słów i czynów) będąca wynikiem ich swoistego sposobu widzenia.

Przejście od motywacji „obiektywnej” do „subiektywnej” jest wszakże nieostre, a pozycje określonych zjawisk na tej skali nie są ustalone raz na zawsze i warunkuje je szereg czynników - kulturowych, historycznych, psychologicznych. W takim dynamicznym ujęciu ikoniczność staje się „ikonizacją" - procesem, operacją umysłową odwołującą się już nie bezpośrednio do rzeczywistości, lecz do struktur pojęciowych będących wynikiem konfrontacji ludzkiego umysłu z otaczającym światem. Kluczowe dla relacji podobieństwa tertium comparationis tkwi nie $w$ rzeczach, lecz w ludzkim umyśle, który dokonuje interpretacji - wybiera i lączy „aspekty rzutowe”. 
Ograniczenie rozważań do systemowych zasad ikoniczności, o których była mowa na wstępie niniejszego eseju, zapewnia językoznawcy komfort w postaci metodologicznej wyrazistości, pozwala na ewidencjonowanie oczywistych formalnych wyznaczników fenomenu. Ceną za ten komfort jest rezygnacja $\mathrm{z}$ analiz jego jednostkowych manifestacji, w których brak takich uchwytnych wskaźników i w których rozmywa się granica między kategoriami zbudowanymi na potrzeby badacza. W miejsce ściśle określonych „obiektywnych” jednostek językowych, do których przywykło językoznawstwo strukturalne, pojawiają się tekst i dyskurs, a wraz z nimi szeroki wachlarz czynników pragmatycznych. Semantyka wkracza na teren zastrzeżony dotąd dla pragmatyki. Przestaje się też ostro rysować granica między kategoriami mimesis i ikoniczności ${ }^{3}$. Interpretacja tekstu staje się domeną zainteresowań językoznawcy, a więc terenem, na którym badacz języka może się spotkać $\mathrm{z}$ badaczem literatury $-\mathrm{z}$ pożytkiem dla obu stron.

\section{BIBLIOGRAFIA}

Arnheim, Rudolf. 1978. Sztuka i percepcja wzrokowa. Psychologia twórczego oka, Warszawa: Wydawnictwa Artystyczne i Filmowe.

Bartmiński, Jerzy. 1990. Punkt widzenia, perspektywa, językowy obraz świata, w: J. Bartmiński [red.], Językowy obraz świata, Lublin: Wydawnictwo UMCS, 109-128.

Behaghel,Otto. 1932. Deutsche Syntax: eine gesichtliche Darstellung. T.iv. Heidelberg: Carl Winters Universitätsbuchhandlung.

Enkvist, Nils Erik. 1990. Discourse comprehension, text strategies and style, AUMLA 73, May 1990.

Fischer, Olga i Nänny Max [wyd.]. 2000. The motivated sign, Amsterdam/Philadelphia: John Benjamins.

Givón, Talmy. 1995. Functionalism and grammar, Amsterdam/Philadelphia: John Benjamins.

Johansen, Jorgen D. 1996. Iconicity in literature. "Semiotica” 110, 37-55.

Johansen, Jorgen D. 2002. Iconizing literature, w: W. G. Müller, i O. Fischer [red.]. 2002. From sign to signing, Amsterdam/Philadelphia: John Benjamins, s. 379-410.

Lakoff, George i Johnson Mark. 1988. Metafory w naszym życiu, przeł. T. P. Krzeszowski, Warszawa: Państwowy Instytut Wydawniczy.

Langacker, Ronald W. 1995. Wyklady z gramatyki kognitywnej. Kazimierz nad Wisla, grudzien 1993, Lublin: Wydawnictwo UMCS .

Langacker, Ronald W. 1999. Subjectification and grammaticization, w: R. W. Langacker, Grammar and Conceptualization, Berlin/Nowy Jork: Mouton de Gruyter, s. 297-315.

Markiewicz, Henryk. 1996. Obrazowość a ikoniczność literatury, w: H. Markiewicz, Wymiary dzieła literackiego, t. IV, Kraków: Universitas, s. 7-42.

${ }^{3}$ Por. Mitosek 2002, zwłaszcza przyp. 1, s. 27. 
Mitosek, Zofia. 2002. „Mimesis” - między udawaniem a referencją. „Przestrzenie Teorii”, nr 1, s. 25-46.

Mayenowa, Maria Renata. 1973. Porównanie nicktórych możliwości tekstów stownych $i$ wizualnych ikonicznych, w: M. R. Mayenowa [red.]. 1973. Seniotyka i struktura tekstu. Studia poświẹcone VII Międzynarodowemu kongresowi slawistów, Wrocław: Ossolineum, s. 45-48.

Müller, Wolfgang G. i Fischer Olga [wyd.]. 2002. From sign to signing, Amsterdam/Philadelphia: John Benjamins.

Nanny, Max i Fischer Olga [wyd.]. 1999. Form miming meaning, Amsterdam/Philadelphia: John Benjamins.

Nöth 2000. Semiotic foundations of iconicity in language and literature, w: O. Fischer i M. Nänny [red.]. The motivated sign, Amsterdam/Philadelphia: John Benjamins, s. $17-28$

Peirce, Charles Sanders. 1955 [1902]. Logic and semiotic: theory of signs, w: J. Bucler [red.] Philosophical writings, NewYork: Dover, s. 98-119.

Sienkiewicz, Barbara. 1992. Literackie „teorie widzenia”, Poznań: Obserwator.

Tabakowska, Elżbieta [red.] 2001. Kognitywne podstawy języka i językoznawstwa, Kraków: Universitas. 